\title{
Natural agents mediated autophagic signal networks in cancer
}

\author{
Eun Jung Sohn ${ }^{1,2^{*}}$ and Hwan Tae Park ${ }^{2}$
}

\begin{abstract}
Recent studies suggested that natural compounds are important in finding targets for cancer treatments. Autophagy ("self-eating") plays important roles in multiple diseases and acts as a tumor suppressor in cancer. Here, we examined the molecular mechanism by which natural agents regulate autophagic signals. Understanding the relationship between natural agents and cellular autophagy may provide more information for cancer diagnosis and chemoprevention.
\end{abstract}

Keywords: Autophagy, MicroRNA, Natural agents

\section{Background}

Autophagy, also called type II programmed cell death, is a catabolic process that leads to degradation of targeted organelles or cellular proteins. The first stage of the autophagic process is the formation of autophagosomes arising from intracellular membrane structures, such as the endoplasmic reticulum (ER), plasma membrane $[1$, 2], Golgi or endosome [1], and the ER-mitochondrial contact site called the mitochondrion-associated ER membrane $[2,3]$.

The serine/threonine protein kinase target of rapamycin (TOR) acts as a central inhibitor of autophagy. In yeast, TOR inhibition mediates the kinase activity of autophagyrelated gene (Atg) 1 and enhances the Atg1 binding affinity to Atg13 and Atg17 to initiate autophagosome formation [4]. The mammalian Atg13/focal adhesion kinase (FAK) family interacting protein of $200 \mathrm{kD}$ (FIP200)/ UNC-51-like kinase complex mediates mechanistic target of rapamycin (mTOR)-mediated autophagy induction [5, 6]. Multiple Atg proteins are required to form the phagophore in autophagosome formation. To initiate the phagophore, the membrane recruits PtdIns3K vacuolar protein sorting 34, the myristoylated serine/threonine kinase Vps15 (p150), Beclin 1, and Atg14 [6-9]. Next, the

\footnotetext{
${ }^{*}$ Correspondence: eunjungs932@hotmail.com

2 Peripheral Neuropathy Research Center, Department of Physiology, College of Medicine, Dong-A University, Dongdaesin-Dong, Seo-Gu, Busan 602-714, Republic of Korea

Full list of author information is available at the end of the article
}

elongation and expansion stages require a ubiquitin-like system such as the ATG5/ATG12/ATG16L multimeric complex and microtubule-associated protein light chain 3 (LC3) processing [10]. Finally, when the autophagosome is mature, it fuses with the lysosome to form the autolysosome' to degrade organelles or cellular proteins.

Autophagy plays a role in several biological processes, such as aging, development, and differentiation [11, 12], and it is regulated by $5^{\prime}$ AMP-activated protein kinase (AMPK) and mTOR downstream of PI3 kinase/AKT, which control cell growth and protein synthesis [13]. When growth factors are withdrawn, the autophagosome forms to induce autophagy [14].

\section{Autophagy and cancer: anti-tumorigenic effects of autophagy}

Autophagy is both inhibitory and beneficial to malignant transformation $[15,16]$. Mukubou et al. showed that enhanced sensitivity of pancreatic cancer cells to gemcitabine or ionizing radiation treatment activated autophagic flux [17]. Interference in the autophagic machinery in heterozygous or homozygous knockout mouse models resulted in oncogenesis [18]. Beclin 1, which regulates the initiation stages of autophagosome formation, plays a role as a tumor suppressor. Beclin $1^{-1-}$ mice displayed tumorigenesis and altered early embryonic development [19]. Beclin $1^{+/-}$immortalized baby mouse kidney (iBMK) epithelial cells promoted tumorigenesis. 
There is evidence that disruption of Atgs promotes tumor cell death induced by anti-cancer drugs, such as histone deacetylase inhibitors, temozolomide, and etoposide [20, 21]. Guo et al. showed that Atg7-deficient lung tumors with $p 53$ deletion resulted in lipid accumulation [22]. Pyo et al. [23] reported that Atg5 regulates interferon- $\gamma$-induced autophagic cell death by interacting with Fas-associated protein with death domain, which is a key signaling molecule involved in cell death.

\section{Autophagy and cancer: pro-tumorigenic effects of autophagy}

Autophagy is constitutively activated in cancer cells, especially RAS-driven tumor cells [24, 25], and transcriptional control of autophagy- and lysosome-related genes induces pancreatic cancer metabolism [18]. Wei et al. [26] demonstrated that deletion of FIP200, which plays a role in autophagy, inhibits mammary tumorigenesis by impairing tumor cell proliferation in vivo in an oncogene-driven tumor model. There are several reports that accumulation of p62, which is a marker of autophagic flux, affects tumorigenesis and/or tumor progression. For instance, expression of p62 is highly induced in nonsmall-cell lung cancer [27] and breast cancer [28], and p62/SQSTM1-knockout mice showed inhibition of RASinduced tumorigenesis compared with wild-type animals [29].

\section{Autophagy and apoptosis}

Beclin 1/Atg six is an essential component involved in formation of autophagic vesicles [30]. As shown in Fig. 1, Beclin 1 interacts with $\mathrm{Bcl}-2$, which is an anti-apoptotic protein $[31,32]$, and inhibits autophagy. The interaction between Beclin 1 and Bcl-2 is via a BH3 domain in Beclin 1 [32, 33], and interference of this interaction was found to enhance autophagy [32].

There is evidence that caspases play important roles in autophagy and apoptosis [34]. Oral et al. [35] reported that caspase- 8 overexpression resulted in Atg3 cleavage and thereby its degradation. Caspase 9 interacts with Atg7, and Caspase9-Atg7 complexes enhanced LC3II activity [35]. Zhu et al. [36] reported that caspase-3 plays an important role in autophagy via cleavage of Beclin-1 at positions 124 and 149. Therefore, crosstalk between autophagy and apoptosis may provide important information for cancer therapy.

\section{Natural agents as modulators of autophagic signals}

Several studies have revealed the therapeutic effectiveness of drug re-positioning of existing drugs and the use of newly developed drugs for the treatment of disease and tumors [37-39]. Natural agents have emerged as novel

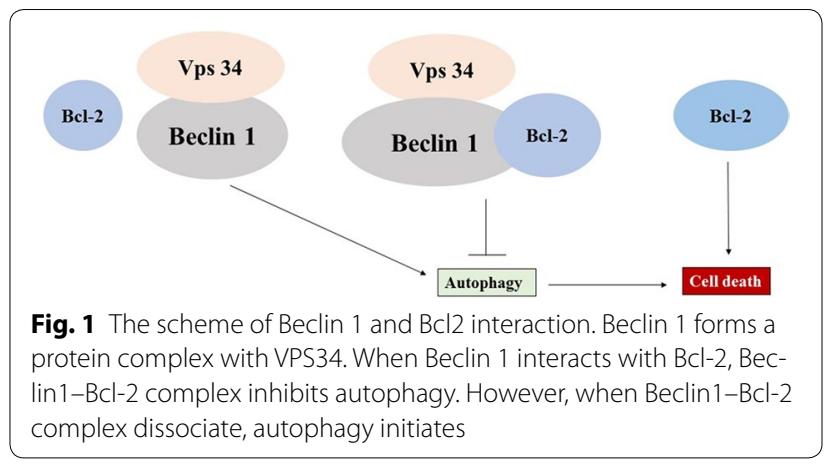

therapeutic agents of drug-repositioning to influence autophagic activity [3]. As shown in Fig. 2, several natural agents modulate autophagy. For example, tanshinone IIA [40], ursolic acid [41], quercerin [42], fisetin [43], resveratrol [44], and honokiol [45] act as inhibitors of the AKT/ mTOR pathway. Tanshinone IIA modulates the initiation of phagophore formation. Ginsensoside [46] and ursolic acid [47] affect the formation of autophagosomes. Ginsenoside RO inhibits autophagosome-lysosome fusion [48].

\section{Resveratrol}

Resveratrol, a polyphenol phytoalexin found in grapes, possesses anti-cancer $[49,50]$ and antioxidant functions [51]. Resveratrol induced apoptosis and autophagy in ovarian cancer cells via inactivation of signal transducer and activator of transcription signaling [52] and induced autophagic cell death in prostate cancer cells via regulation of stromal interaction molecule 1 [53]. It also induced autophagy via downregulation of the Wnt $/ \beta$-catenin signaling pathway in breast cancer stem-like cells [54]. Ge et al. [44] reported that resveratrol induced autophagy and apoptosis via repression of AKT/mTOR/p70S6K/4E-BP1 and enhancement of p38 MAPK signaling in T cell acute lymphoblastic leukemia cells.

\section{Apigenin}

Apigenin (4',5,7-trihydroxyflavone), a naturally occurring flavone found in many fruits (apples, grapes), vegetables (onions, parsley), and tea, was shown to have chemopreventive effects in vitro and in vivo $[55,56]$. Lee et al. [57] showed that apigenin induced autophagy in HCT116 human colon cancer cells, and when combined with 3MA, which inhibits autophagy, it increased apigenininduced apoptosis in HCT116 cells. Autophagy inhibition enhanced apigenin-induced apoptosis in breast cancer T47D cells [58]. Apigenin induced autophagic cell death via reactive oxygen species (ROS) production and accumulation of G2/M cell cycle arrest in human papillary thyroid carcinoma cells [59]. 


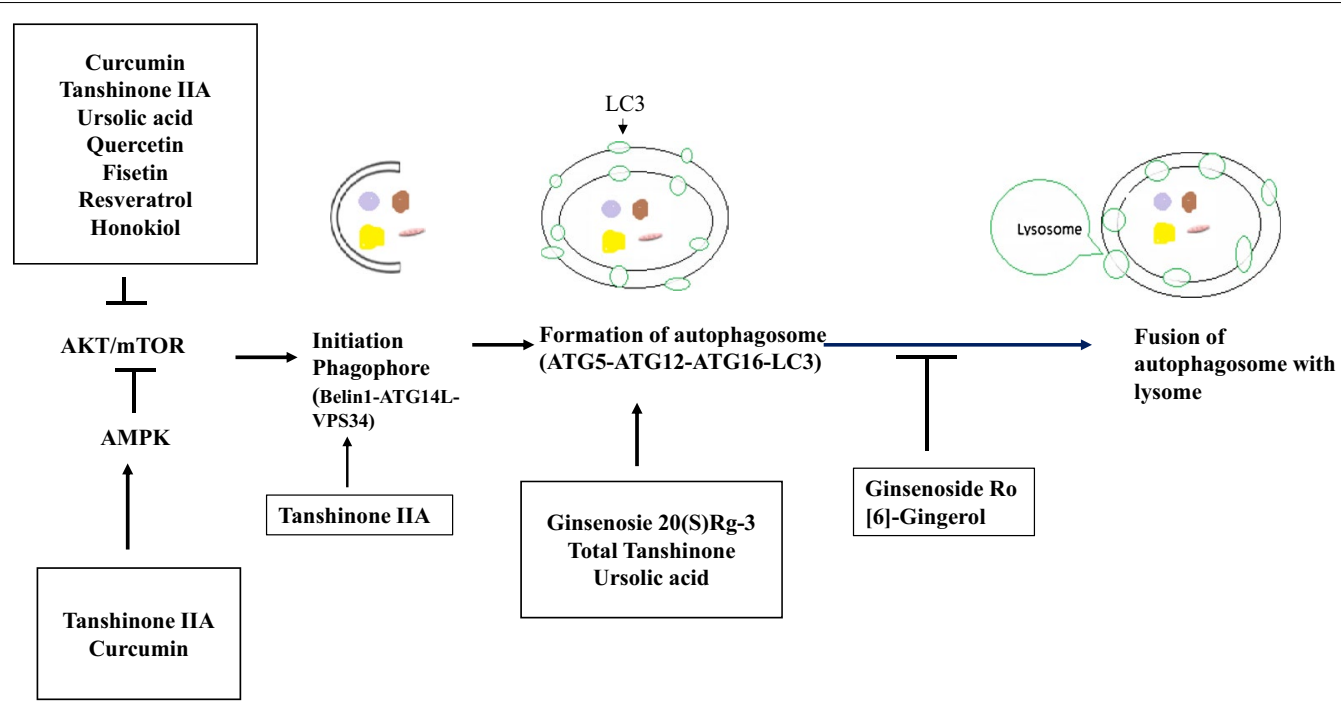

Fig. 2 The autophagic signal by natural agents. Curcumin, Tanshinone IIA, ursolic acid, quercetin, fisetin, resveratrol, and honokiol inhibit AKT/mTOR pathway. Tanshinone IIA and curcumin also enhance activation of AMPK which inhibits AKT/mTOR pathway. Tanshinone IIA modulates the initiation of phagophore formation. Ginsenoside 20(S) Rg-3, total tanshinone and ursolic acid enhance the formation of autophagosomes. Ginsenoside RO and [6]-Gingerol inhibit autophagosome-lysosome fusion

\section{Ursolic acid}

Ursolic acid, a pentacyclic triterpenoid known for its anti-tumor effects [60, 61], increased the expression of LC3-II, an autophagosome marker, and induced autophagy via the Beclin-1 and AKT/mTOR pathways. In addition, treatment with 3-methyladeninet or Beclin-1/Atg5 siRNAs enhanced ursolic acid-mediated cell cytotoxicity in prostate cancer cells [62]. Xavier et al. [47] reported that ursolic acid induced accumulation of both LC3-II and p62 by activation of JNK in HCT15 cells. Zhao et al. [63] demonstrated that ursolic acid treatment induced autophagy via eukaryotic translation initiation factor $2-\alpha$ kinase 3 activity, implying that ER stress is an important factor in autophagy. Leng et al. also demonstrated that ursolic acid treatment led to apoptosis in cervical cancer TC-1 cells and, according to transmission electron microscopy, resulted in autophagic vacuoles. siRNA-mediated knockdown of Atg5 combined with ursolic acid treatment in TC-1 tumor cells attenuated LC3 II accumulation, as shown by Western blotting, implying that the ursolic acid-induced autophagy relies on Atg5 [64].

\section{Tanshinone}

Tanshinones (tanshinone I and IIA) are derived from a traditional Chinese herb and are well-known bioactive herbal compounds with chemopreventive properties [65]. Tanshinone IIA activated LC3 II expression in various cancer cells, such as prostate and gastric cells $[66,67]$. It also induced apoptosis and autophagy via the mTOR/p70S6K/AMPK pathway in KBM-5 leukemia cells [68]. Gao et al. [40] reported that treatment of 95D cells with total tanshinones upregulated the expression of autophagic proteins, such as Atg3, Atg5, Atg7, Atg12, Beclin-1, and LC3II, in a dose-dependent manner. Jing et al. demonstrated that tanshinone treatment of gastric cancer cells, such as BGC823 and SGC7901 cells, induced autophagy and attenuated tumor proliferation in nude mice bearing BGC823 tumor xenografts [66]. Tanshinone II treatment in human osteosarcoma MG63 cells upregulated Beclin, which is involved in the formation of autophagic vesicles, inducing autophagy and apoptosis via ROS [69].

\section{Curcumin}

Curcumin, a hydrophobic polyphenol, possesses anticancer functions in various human cancer cells, such as pancreatic and prostate cancer cells [70, 71]. Zhang et al. [72] reported that curcumin treatment of colon cancer HCT116 cells induces autophagy via inhibition of the AKT/mTOR signaling pathway and upregulation of the transcriptional activity of the transcription factor EB. Guan et al. [73] also demonstrated that curcumin treatment induced autophagy via activation of AMPK and suppressed the proliferation and migration of MDA-MB-231 breast cancer cells. Curcumin induced autophagy by upregulating the AMPK pathway in A549 lung adenocarcinoma cells as well [74]. Zhao et al. [75] showed that curcumin treatment induced autophagy and suppressed invasion and proliferation in 
human melanoma cells via inhibition of the AKT/mTOR pathway.

\section{Ginsenoside}

Kim et al. reported that ginsenoside $\operatorname{Rg} 3$ treatment of hepatocellular carcinoma, using a GFP-mRFP-LC3 construct, suppressed autophagic flux. Combined treatment with doxorubicin and ginsenoside $\mathrm{Rg} 3$ sensitized cells to death via inhibition of autophagic flux [76]. Ginsenoside 20 (S)-Rg3 treatment of ovarian cancer cells inhibited cell growth and invasion while upregulating autophagic related molecules, such as LC3II, ATG5, and ATG7. Ginsenoside 20(S)-Rg3 treatment suppressed tumor growth while upregulating LC3II, ATG5, and ATG7 levels [46]. Zheng et al. [48] showed that ginsenoside RO (RO) treatment combined with chloroquine diphosphate did not enhance LC3 II accumulation in esophageal cancer, implying that RO inhibits autophagosome-lysosome fusion.

\section{Fisetin}

Fisetin $\left(3,3^{\prime}, 4^{\prime}, 7\right.$-tetrahydroxyflavone) is a flavonoid present in fruits and vegetables [77] that possesses anticancer [78], anti-inflammatory [79], and antioxidative [80] actions. Suh et al. [43] showed that fisetin treatment inhibited the growth of PC3Cap cells and induced LC3II autophagic marker expression via inhibition of mTOR1/2 signaling. Klimaszewska-Wisniewska et al. observed that combined treatment of fisetin and paclitaxel induced autophagic cell death in A549 non-small-cell lung cancer cells [81].

\section{Oridonin}

Treatment with oridonin, an active diterpenoid compound isolated from Rabdosia rubescens, simultaneously induced apoptosis and autophagy via ROS in HeLa cells [82] and human multiple myeloma RPMI8266 cells [83]. Oridonin induced apoptosis and autophagy in human prostate cancer cells [84]. Treatment with the nitric oxide (NO) scavenger DTT and interruption of ERK and p53 activation by PD98059, pifithrin- $\alpha$, or ERK siRNA decreased oridonin-induced apoptosis and autophagy. This indicates that NO/ERK/p53 inhibited oridonininduced apoptosis and autophagy in L929 cells [85].

\section{Piperlonguminine}

Piperlonguminine, from the long pepper (Piper longum), possesses anti-tumor activity [86] and suppresses the phosphorylation of $\mathrm{AKT} / \mathrm{mTOR}$, thereby upregulating ROS levels in several cancer cells, such as 786-O, PC-3, and MCF-7 cell lines [87]. Piperlongumine-induced autophagy depends on ROS activation [87]. Xiong et al. [88] also reported that piperlonguminine significantly induced apoptotic molecules such as Bax, Bcl-2, and caspase-3, autophagic markers such as Beclin-1 and LC3B, phosphorylation of p38 and JNK, and ROS levels in bone marrow mononuclear cells from patients with myeloid leukemia. Piperlonguminine activated $\mathrm{p} 38$ protein kinase via ROS, and SB203580, a p38 inhibitor, inhibited piperlonguminine-mediated autophagy [89].

\section{Honokiol}

Honokiol, 2-(4-hydroxy-3-prop-2-enyl-phenyl)-4-prop2-enyl-phenol), a small molecule polyphenol, induced both autophagy and apoptosis via inhibition of the PI3K/ $\mathrm{AKT} / \mathrm{mTOR}$ pathway in neuroblastoma cells [45]. Lu et al. showed that honokiol treatment of human thyroid cancer cells induced anti-tumorigenic effects in vitro and in vivo. LC3-II activity, a marker of autophagy, was increased by honokiol treatment in concentration- and time-dependent manners in thyroid cancer cells [90].

\section{Others \\ Quercetin}

Quercetin, a dietary antioxidant present in fruits and vegetables, is a chemopreventive compound. Wang et al. [42] reported that quercetin induced the appearance of autophagic vacuoles and formation of acidic vesicular organelles, with conversion of LC3-I to LC3-II via modulation of $\mathrm{AKT} / \mathrm{mTOR}$ and hypoxia-induced factor $1 \alpha$ signaling in gastric cancer cells.

\section{[6]-Gingerol}

Treatment with gingerol, which has anti-cancer effects, blocked autophagic flux, and gingerol combined with TRAIL sensitized cell death by blocking autophagic flux in A549 lung adenocarcinoma cells [91].

\section{Glabridin}

Glabridin, an isoflavone, induced autophagy and apoptosis in Huh7 human liver cancer cells via activation of JNK1/2. Autophagy inhibitors, such as wortmannin and BafA1, enhanced glabridin-mediated apoptosis [92].

\section{Conclusions}

The induction of autophagy is regarded as a strategy for cancer prevention because of its function as a tumor suppressor. Inhibition of the PI3K/AKT/mTOR signaling pathway, which is dysregulated in human tumors, affects autophagy. As shown in Fig. 2 and Table 1, natural agents 
Table 1 Mechanism of natural agents that induce autophagy and apoptosis in cancer cells

\begin{tabular}{|c|c|c|c|}
\hline Natural agents & Cancer cell line & Pathway & References \\
\hline Resveratrol & Ovarian cancer cells & STAT3 & {$[52]$} \\
\hline \multirow[t]{4}{*}{ Ursolic acid } & Prostate cancer cell & Beclin-1/Akt/mTOR & {$[62]$} \\
\hline & Colorectal cancer cells with p53 mutant & JNK & {$[47]$} \\
\hline & MCF-7 human breast cancer cells & EIF2AK3 & {$[63]$} \\
\hline & Cervical cancer cells TC-1 & ATG5 & {$[64]$} \\
\hline \multirow[t]{2}{*}{ Tanshione IIA } & KBM-5 leukemia cells. & mTOR/p70S6K/AMPK & {$[68]$} \\
\hline & Lung cancer 95D cells & ROS & {$[40]$} \\
\hline \multirow[t]{2}{*}{ Curcumin } & Human colon cancer HCT116 cells & Transcription factor EB (TFEB) & {$[72]$} \\
\hline & Human melanoma cells & $\mathrm{AKT} / \mathrm{mTOR}$ & {$[75]$} \\
\hline Ginsenoside 20(S)-Rg3 & Ovarian cancer & LC3II, ATG5, and ATG7 & {$[46]$} \\
\hline Fisetin & Prostate cancer cells & mTOR & {$[43]$} \\
\hline Oridonin & Human cervical carcinoma Hela cells & ROS & {$[82]$} \\
\hline Honokiol & Neuroblastoma cells & $\mathrm{PI} 3 \mathrm{~K} / \mathrm{Akt} / \mathrm{mTOR}$ & {$[45]$} \\
\hline Piperlongumine & Myeloid leukemias & P38/ROS & {$[88]$} \\
\hline
\end{tabular}

regulate various autophagic signals. Therefore, finding natural agents that suppress PI3K/AKT/mTOR signaling or induce autophagy may be a good strategy for cancer chemoprevention.

\section{Abbreviations}

AMPK: AMP-activated protein kinase; CQ: chloroquine diphosphate; ER: endoplasmic reticulum; LC3: microtubule-associated protein light chain 3; mTOR: mechanistic target of rapamycin; NSCLC: non-small-cell lung cancer; PI3K: class III phosphatidylinositol 3-kinase; ROS: reactive oxygen species; STIM1: stromal interaction molecule 1.

\section{Authors' contributions}

Conception and design, contribution of reagents, wrote the paper: EJS. HTP designed and prepared the manuscript. Both authors read and approved the final manuscript

\section{Author details}

${ }^{1}$ College of Korean Medicine, Kyung Hee University, 1 Hoegi-dong, Dongdaemun-gu, Seoul 130-701, Republic of Korea. ${ }^{2}$ Peripheral Neuropathy Research Center, Department of Physiology, College of Medicine, Dong-A University, Dongdaesin-Dong, Seo-Gu, Busan 602-714, Republic of Korea.

\section{Acknowledgements}

Not applicable.

\section{Competing interests}

The authors declare that they have no competing interests.

\section{Availability of data and materials}

All data is included in the manuscript.

\section{Consent for publication}

The authors consent for publication.

\section{Ethical approval and consent to participate}

This article does not contain any studies with human participants and animals performed by any of the authors.

\section{Funding}

This was supported by the National Research Foundation of Korea (NRF) Grant funded by Basic Research Program (2015R1C1A1A02036842 and 2016R1A5A2007009).

\section{Publisher's Note}

Springer Nature remains neutral with regard to jurisdictional claims in published maps and institutional affiliations.

Received: 13 March 2017 Accepted: 23 November 2017

Published online: 28 November 2017

References

1. Axe EL, Walker SA, Manifava M, Chandra P, Roderick HL, Habermann A, Griffiths G, Ktistakis NT. Autophagosome formation from membrane compartments enriched in phosphatidylinositol 3-phosphate and dynamically connected to the endoplasmic reticulum. J Cell Biol. 2008;182(4):685-701

2. Hamasaki M, Furuta N, Matsuda A, Nezu A, Yamamoto A, Fujita N, Oomori H, Noda T, Haraguchi T, Hiraoka Y, et al. Autophagosomes form at ERmitochondria contact sites. Nature. 2013:495(7441):389-93.

3. Chan SN, Tang BL. Location and membrane sources for autophagosome formation-from ER-mitochondria contact sites to Golgi-endosomederived carriers. Mol Membr Biol. 2013;30(8):394-402.

4. Kamada Y, Funakoshi T, Shintani T, Nagano K, Ohsumi M, Ohsumi Y. Tormediated induction of autophagy via an Apg1 protein kinase complex. J Cell Biol. 2000;150(6):1507-13.

5. Jung $\mathrm{CH}$, Jun $\mathrm{CB}$, Ro SH, Kim YM, Otto NM, Cao J, Kundu M, Kim DH. ULK-Atg13-FIP200 complexes mediate mTOR signaling to the autophagy machinery. Mol Biol Cell. 2009;20(7):1992-2003.

6. Liang XH, Jackson S, Seaman M, Brown K, Kempkes B, Hibshoosh H, Levine $\mathrm{B}$. Induction of autophagy and inhibition of tumorigenesis by beclin 1. Nature. 1999;402(6762):672-6.

7. Itakura E, Kishi C, Inoue K, Mizushima N. Beclin 1 forms two distinct phosphatidylinositol 3-kinase complexes with mammalian Atg14 and UVRAG. Mol Biol Cell. 2008;19(12):5360-72.

8. Kihara A, Noda T, Ishihara N, Ohsumi Y. Two distinct Vps34 phosphatidylinositol 3-kinase complexes function in autophagy and carboxypeptidase $Y$ sorting in Saccharomyces cerevisiae. J Cell Biol. 2001;152(3):519-30.

9. Sun Q, Fan W, Chen K, Ding X, Chen S, Zhong Q. Identification of Barkor as a mammalian autophagy-specific factor for Beclin 1 and class III phosphatidylinositol 3-kinase. Proc Natl Acad Sci USA. 2008;105(49):19211-6.

10. He C, Klionsky DJ. Regulation mechanisms and signaling pathways of autophagy. Annu Rev Genet. 2009;43:67-93.

11. Levine B, Kroemer G. Autophagy in aging, disease and death: the true identity of a cell death impostor. Cell Death Differ. 2009;16(1):1-2. 
12. Mizushima N, Levine B. Autophagy in mammalian development and differentiation. Nat Cell Biol. 2010;12(9):823-30.

13. Shang L, Wang X. AMPK and mTOR coordinate the regulation of Ulk1 and mammalian autophagy initiation. Autophagy. 2011;7(8):924-6.

14. Lum JJ, Bauer DE, Kong M, Harris MH, Li C, Lindsten T, Thompson CB. Growth factor regulation of autophagy and cell survival in the absence of apoptosis. Cell. 2005;120(2):237-48.

15. Galluzzi L, Pietrocola F, Bravo-San Pedro JM, Amaravadi RK, Baehrecke EH, Cecconi F, Codogno P, Debnath J, Gewirtz DA, Karantza V, et al. Autophagy in malignant transformation and cancer progression. EMBO J. 2015;34(7):856-80.

16. Ravikumar B, Sarkar S, Davies JE, Futter M, Garcia-Arencibia M, GreenThompson ZW, Jimenez-Sanchez M, Korolchuk VI, Lichtenberg M, Luo S, et al. Regulation of mammalian autophagy in physiology and pathophysiology. Physiol Rev. 2010;90(4):1383-435.

17. Mukubou H, Tsujimura T, Sasaki R, Ku Y. The role of autophagy in the treatment of pancreatic cancer with gemcitabine and ionizing radiation. Int J Oncol. 2010;37(4):821-8.

18. Perera RM, Stoykova S, Nicolay BN, Ross KN, Fitamant J, Boukhali M, Lengrand J, Deshpande V, Selig MK, Ferrone CR, et al. Transcriptional control of autophagy-lysosome function drives pancreatic cancer metabolism. Nature. 2015;524(7565):361-5

19. Yue Z, Jin S, Yang C, Levine AJ, Heintz N. Beclin 1, an autophagy gene essential for early embryonic development, is a haploinsufficient tumor suppressor. Proc Natl Acad Sci USA. 2003;100(25):15077-82.

20. Carew JS, Nawrocki ST, Kahue CN, Zhang H, Yang C, Chung L, Houghton $J A$, Huang P, Giles FJ, Cleveland JL. Targeting autophagy augments the anticancer activity of the histone deacetylase inhibitor SAHA to overcome Bcr-Abl-mediated drug resistance. Blood. 2007;1 10(1):313-22.

21. Katayama M, Kawaguchi T, Berger MS, Pieper RO. DNA damaging agentinduced autophagy produces a cytoprotective adenosine triphosphate surge in malignant glioma cells. Cell Death Differ. 2007;14(3):548-58.

22. Guo JY, Karsli-Uzunbas G, Mathew R, Aisner SC, Kamphorst JJ, Strohecker AM, Chen G, Price S, Lu W, Teng X, et al. Autophagy suppresses progression of K-ras-induced lung tumors to oncocytomas and maintains lipid homeostasis. Genes Dev. 2013;27(13):1447-61.

23. Pyo JO, Jang MH, Kwon YK, Lee HJ, Jun JI, Woo HN, Cho DH, Choi B, Lee H, $\mathrm{Kim} \mathrm{JH}$, et al. Essential roles of Atg5 and FADD in autophagic cell death: dissection of autophagic cell death into vacuole formation and cell death. J Biol Chem. 2005;280(21):20722-9.

24. Kimmelman AC. The dynamic nature of autophagy in cancer. Genes Dev. 2011;25(19):1999-2010.

25. Ancrile B, Lim KH, Counter CM. Oncogenic Ras-induced secretion of IL6 is required for tumorigenesis. Genes Dev. 2007;21(14):1714-9.

26. Wei H, Guan JL. Pro-tumorigenic function of autophagy in mammary oncogenesis. Autophagy. 2012;8(1):129-31.

27. Inoue D, Suzuki T, Mitsuishi Y, Miki Y, Suzuki S, Sugawara S, Watanabe M, Sakurada A, Endo C, Uruno A, et al. Accumulation of p62/SQSTM1 is associated with poor prognosis in patients with lung adenocarcinoma. Cancer Sci. 2012;103(4):760-6.

28. Thompson HG, Harris JW, Wold BJ, Lin F, Brody JP. p62 overexpression in breast tumors and regulation by prostate-derived Ets factor in breast cancer cells. Oncogene. 2003;22(15):2322-33.

29. Duran A, Linares JF, Galvez AS, Wikenheiser K, Flores JM, Diaz-Meco MT, Moscat J. The signaling adaptor p62 is an important NF-kappaB mediator in tumorigenesis. Cancer Cell. 2008;13(4):343-54.

30. Sun Q, Fan W, Zhong Q. Regulation of Beclin 1 in autophagy. Autophagy. 2009;5(5):713-6.

31. Marquez RT, Xu L. BCl-2: beclin 1 complex: multiple, mechanisms regulating autophagy/apoptosis toggle switch. Am J Cancer Res. 2012;2(2):214-21.

32. Maiuri MC, Le Toumelin G, Criollo A, Rain JC, Gautier F, Juin P, Tasdemir E, Pierron G, Troulinaki K, Tavernarakis N, et al. Functional and physical interaction between $\mathrm{BCl}-\mathrm{X}(\mathrm{L})$ and a BH3-like domain in Beclin-1. EMBO J. 2007;26(10):2527-39.

33. Feng $\mathrm{W}$, Huang $\mathrm{S}, \mathrm{Wu} \mathrm{H}$, Zhang M. Molecular basis of Bcl-xL's target recognition versatility revealed by the structure of $\mathrm{BCl}-\mathrm{xL}$ in complex with the BH3 domain of Beclin-1. J Mol Biol. 2007;372(1):223-35.

34. Riedl SJ, Shi Y. Molecular mechanisms of caspase regulation during apoptosis. Nat Rev Mol Cell Biol. 2004;5(11):897-907.
35. Oral O, Oz-Arslan D, Itah Z, Naghavi A, Deveci R, Karacali S, Gozuacik D. Cleavage of Atg3 protein by caspase-8 regulates autophagy during receptor-activated cell death. Apoptosis. 2012;17(8):810-20.

36. Zhu Y, Zhao L, Liu L, Gao P, Tian W, Wang X, Jin H, Xu H, Chen Q. Beclin 1 cleavage by caspase-3 inactivates autophagy and promotes apoptosis. Protein Cell. 2010;1(5):468-77.

37. Shim JS, Liu JO. Recent advances in drug repositioning for the discovery of new anticancer drugs. Int J Biol Sci. 2014;10(7):654-63.

38. Bernstein WB, Dennis PA. Repositioning HIV protease inhibitors as cancer therapeutics. Curr Opin HIV AIDS. 2008;3(6):666-75.

39. Dolma S, Selvadurai HJ, Lan X, Lee L, Kushida M, Voisin V, Whetstone $H$, So M, Aviv T, Park N, et al. Inhibition of dopamine receptor D4 impedes autophagic flux, proliferation, and survival of glioblastoma stem cells. Cancer Cell. 2016;29(6):859-73.

40. Gao H, Sun W, Zhao W, Hao W, Leung CH, Lu J, Chen X. Total tanshinonesinduced apoptosis and autophagy via reactive oxygen species in lung cancer 95D cells. Am J Chin Med. 2015;43(6):1265-79.

41. Meng Y, Lin ZM, Ge N, Zhang DL, Huang J, Kong F. Ursolic acid induces apoptosis of prostate cancer cells via the PI3K/Akt/mTOR pathway. Am J Chin Med. 2015:43(7):1471-86.

42. Wang K, Liu R, Li J, Mao J, Lei Y, Wu J, Zeng J, Zhang T, Wu H, Chen L, et al. Quercetin induces protective autophagy in gastric cancer cells: involvement of Akt-mTOR- and hypoxia-induced factor 1alpha-mediated signaling. Autophagy. 2011;7(9):966-78.

43. Suh Y, Afaq F, Khan N, Johnson JJ, Khusro FH, Mukhtar H. Fisetin induces autophagic cell death through suppression of mTOR signaling pathway in prostate cancer cells. Carcinogenesis. 2010;31(8):1424-33.

44. Ge J, Liu Y, Li Q, Guo X, Gu L, Ma ZG, Zhu YP. Resveratrol induces apoptosis and autophagy in T-cell acute lymphoblastic leukemia cells by inhibiting Akt/mTOR and activating p38-MAPK. Biomed Environ Sci BES. 2013;26(11):902-11.

45. Yeh PS, Wang W, Chang YA, Lin CJ, Wang JJ, Chen RM. Honokiol induces autophagy of neuroblastoma cells through activating the PI3K/Akt/mTOR and endoplasmic reticular stress/ERK1/2 signaling pathways and suppressing cell migration. Cancer Lett. 2016;370(1):66-77.

46. Zheng X, Chen W, Hou H, Li J, Li H, Sun X, Zhao L, Li X. Ginsenoside 20(S)Rg3 induced autophagy to inhibit migration and invasion of ovarian cancer. Biomed Pharmacother Biomed Pharmacother. 2017:85:620-6.

47. Xavier CP, Lima CF, Pedro DF, Wilson JM, Kristiansen K, Pereira-Wilson C. Ursolic acid induces cell death and modulates autophagy through JNK pathway in apoptosis-resistant colorectal cancer cells. J Nutr Biochem. 2013;24(4):706-12.

48. Zheng K, Li Y, Wang S, Wang X, Liao C, Hu X, Fan L, Kang Q, Zeng Y, Wu X, et al. Inhibition of autophagosome-lysosome fusion by ginsenoside Ro via the ESR2-NCF1-ROS pathway sensitizes esophageal cancer cells to 5-fluorouracil-induced cell death via the CHEK1-mediated DNA damage checkpoint. Autophagy. 2016;12(9):1593-613.

49. Sun W, Wang W, Kim J, Keng P, Yang S, Zhang H, Liu C, Okunieff P, Zhang L. Anti-cancer effect of resveratrol is associated with induction of apoptosis via a mitochondrial pathway alignment. Adv Exp Med Biol. 2008:614:179-86.

50. Karimi Dermani F, Saidijam M, Amini R, Mahdavinezhad A, Heydari K, Najafi R. Resveratrol inhibits proliferation, invasion, and epithelial-mesenchymal transition by increasing miR-200c expression in HCT-116 colorectal cancer cells. J Cell Biochem. 2016;118:1547.

51. Kavas GO, Ayral PA, Elhan AH. The effects of resveratrol on oxidant/ antioxidant systems and their cofactors in rats. Adv Clin Exp Med. 2013;22(2):151-5.

52. Zhong LX, Zhang Y, Wu ML, Liu YN, Zhang P, Chen XY, Kong QY, Liu J, Li H. Resveratrol and STAT inhibitor enhance autophagy in ovarian cancer cells. Cell Death Discov. 2016;2:15071.

53. Selvaraj S, Sun Y, Sukumaran P, Singh BB. Resveratrol activates autophagic cell death in prostate cancer cells via downregulation of STIM1 and the mTOR pathway. Mol Carcinog. 2016;55(5):818-31.

54. Fu Y, Chang H, Peng X, Bai Q, Yi L, Zhou Y, Zhu J, Mi M. Resveratrol inhibits breast cancer stem-like cells and induces autophagy via suppressing Wnt/beta-catenin signaling pathway. PLoS ONE. 2014;9(7):e102535.

55. Patel D, Shukla S, Gupta S. Apigenin and cancer chemoprevention: progress, potential and promise (review). Int J Oncol. 2007;30(1):233-45.

56. Shukla S, Gupta S. Apigenin: a promising molecule for cancer prevention. Pharm Res. 2010;27(6):962-78. 
57. Lee Y, Sung B, Kang YJ, Kim DH, Jang JY, Hwang SY, Kim M, Lim HS, Yoon $\mathrm{JH}$, Chung HY, et al. Apigenin-induced apoptosis is enhanced by inhibition of autophagy formation in HCT116 human colon cancer cells. Int J Oncol. 2014;44(5):1599-606

58. Cao X, Liu B, Cao W, Zhang W, Zhang F, Zhao H, Meng R, Zhang L, Niu R, Hao X, et al. Autophagy inhibition enhances apigenin-induced apoptosis in human breast cancer cells. Chin J Cancer Res Chung-kuo yen cheng yen chiu. 2013;25(2):212-22.

59. Zhang L, Cheng X, Gao Y, Zheng J, Xu Q, Sun Y, Guan H, Yu H, Sun Z. Apigenin induces autophagic cell death in human papillary thyroid carcinoma BCPAP cells. Food Funct. 2015;6(11):3464-72.

60. Gai WT, Yu DP, Wang XS, Wang PT. Anti-cancer effect of ursolic acid activates apoptosis through ROCK/PTEN mediated mitochondrial translocation of cofilin-1 in prostate cancer. Oncol Lett. 2016;12(4):2880-5.

61. Kim SH, Ryu HG, Lee J, Shin J, Harikishore A, Jung HY, Kim YS, Lyu HN, Oh E, Baek NI, et al. Ursolic acid exerts anti-cancer activity by suppressing vaccinia-related kinase 1-mediated damage repair in lung cancer cells. Sci Rep. 2015;5:14570.

62. Shin SW, Kim SY, Park JW. Autophagy inhibition enhances ursolic acid-induced apoptosis in PC3 cells. Biochem Biophys Acta. 2012;1823(2):451-7.

63. Zhao C, Yin S, Dong Y, Guo X, Fan L, Ye M, Hu H. Autophagy-dependent EIF2AK3 activation compromises ursolic acid-induced apoptosis through upregulation of MCL1 in MCF-7 human breast cancer cells. Autophagy. 2013;9(2):196-207.

64. Leng S, Hao Y, Du D, Xie S, Hong L, Gu H, Zhu X, Zhang J, Fan D, Kung HF. Ursolic acid promotes cancer cell death by inducing Atg5-dependent autophagy. Int J Cancer. 2013;133(12):2781-90.

65. Zhou L, Zuo Z, Chow MS. Danshen: an overview of its chemistry, pharmacology, pharmacokinetics, and clinical use. J Clin Pharmacol. 2005:45(12):1345-59.

66. Jing $X, X u Y$, Cheng W, Guo S, Zou Y, He L. Tanshinone I induces apoptosis and pro-survival autophagy in gastric cancers. Cancer Chemother Pharmacol. 2016;77(6):1171-81.

67. Li C, Han X, Zhang H, Wu J, Li B. The interplay between autophagy and apoptosis induced by tanshinone IIA in prostate cancer cells. Tumour Biol J Int Soc Oncodev Biol Med. 2016;37(6):7667-74.

68. Yun SM, Jung JH, Jeong SJ, Sohn EJ, Kim B, Kim SH. Tanshinone IIA induces autophagic cell death via activation of AMPK and ERK and inhibition of mTOR and p70 S6K in KBM-5 leukemia cells. Phytother Res PTR. 2014;28(3):458-64.

69. Ding L, Wang S, Qu X, Wang J. Tanshinone IIA sensitizes oral squamous cell carcinoma to radiation due to an enhanced autophagy. Environ Toxicol Pharmacol. 2016;46:264-9.

70. Zhao Z, Li C, Xi H, Gao Y, Xu D. Curcumin induces apoptosis in pancreatic cancer cells through the induction of forkhead box 01 and inhibition of the PI3K/Akt pathway. Mol Med Rep. 2015;12(4):5415-22.

71. Killian PH, Kronski E, Michalik KM, Barbieri O, Astigiano S, Sommerhoff CP, Pfeffer U, Nerlich AG, Bachmeier BE. Curcumin inhibits prostate cancer metastasis in vivo by targeting the inflammatory cytokines CXCL1 and -2 . Carcinogenesis. 2012;33(12):2507-19.

72. Zhang J, Wang J, Xu J, Lu Y, Jiang J, Wang L, Shen HM, Xia D. Curcumin targets the TFEB-lysosome pathway for induction of autophagy. Oncotarget. 2016;7:75659.

73. Guan F, Ding Y, Zhang Y, Zhou Y, Li M, Wang C. Curcumin suppresses proliferation and migration of MDA-MB-231 breast cancer cells through autophagy-dependent Akt degradation. PLoS ONE. 2016;11(1):e0146553.

74. Xiao K, Jiang J, Guan C, Dong C, Wang G, Bai L, Sun J, Hu C, Bai C. Curcumin induces autophagy via activating the AMPK signaling pathway in lung adenocarcinoma cells. J Pharmacol Sci. 2013;123(2):102-9.

75. Zhao G, Han X, Zheng S, Li Z, Sha Y, Ni J, Sun Z, Qiao S, Song Z. Curcumin induces autophagy, inhibits proliferation and invasion by downregulating AKT/mTOR signaling pathway in human melanoma cells. Oncol Rep. 2016:35(2):1065-74

76. Kim DG, Jung KH, Lee DG, Yoon JH, Choi KS, Kwon SW, Shen HM, Morgan MJ, Hong SS, Kim YS. 20(S)-Ginsenoside Rg3 is a novel inhibitor of autophagy and sensitizes hepatocellular carcinoma to doxorubicin. Oncotarget. 2014;5(12):4438-51.

77. Manach C, Scalbert A, Morand C, Remesy C, Jimenez L. Polyphenols: food sources and bioavailability. Am J Clin Nutr. 2004;79(5):727-47.
78. Youns M, Hegazy WAH. The natural flavonoid fisetin inhibits cellular proliferation of hepatic, colorectal, and pancreatic cancer cells through modulation of multiple signaling pathways. PLoS ONE. 2017;12(1):e0169335.

79. Jeong HY, Sung GH, Kim JH, Yoon JY, Yang Y, Park JG, Kim SH, Yi YS, Yang WS, Yoon DH, et al. Syk and Src are major pharmacological targets of a Cerbera manghas methanol extract with kaempferol-based anti-inflammatory activity. J Ethnopharmacol. 2014;151(2):960-9.

80. Khan N, Syed DN, Ahmad N, Mukhtar H. Fisetin: a dietary antioxidant for health promotion. Antioxid Redox Signal. 2013;19(2):151-62.

81. Klimaszewska-Wisniewska A, Halas-Wisniewska M, Tadrowski T, Gagat M, Grzanka D, Grzanka A. Paclitaxel and the dietary flavonoid fisetin: a synergistic combination that induces mitotic catastrophe and autophagic cell death in A549 non-small cell lung cancer cells. Cancer Cell Int. 2016;16:10

82. Zhang YH, Wu YL, Tashiro S, Onodera S, Ikejima T. Reactive oxygen species contribute to oridonin-induced apoptosis and autophagy in human cervical carcinoma HeLa cells. Acta Pharmacol Sin. 2011;32(10):1266-75.

83. Zeng R, Chen Y, Zhao S, Cui GH. Autophagy counteracts apoptosis in human multiple myeloma cells exposed to oridonin in vitro via regulating intracellular ROS and SIRT1. Acta Pharmacol Sin. 2012;33(1):91-100.

84. Li X, Li X, Wang J, Ye Z, Li JC. Oridonin up-regulates expression of P21 and induces autophagy and apoptosis in human prostate cancer cells. Int J Biol Sci. 2012:8(6):901-12.

85. Ye YC, Wang HJ, Xu L, Liu WW, Liu BB, Tashiro S, Onodera S, Ikejima T. Oridonin induces apoptosis and autophagy in murine fibrosarcoma L929 cells partly via NO-ERK-p53 positive-feedback loop signaling pathway. Acta Pharmacol Sin. 2012;33(8):1055-61.

86. Bezerra DP, Pessoa C, Moraes MO, Alencar NM, Mesquita RO, Lima MW, Alves AP, Pessoa OD, Chaves JH, Silveira ER, et al. In vivo growth inhibition of sarcoma 180 by piperlonguminine, an alkaloid amide from the Piper species. J Appl Toxicol JAT. 2008;28(5):599-607.

87. Makhov P, Golovine K, Teper E, Kutikov A, Mehrazin R, Corcoran A, Tulin A, Uzzo RG, Kolenko VM. Piperlongumine promotes autophagy via inhibition of Akt/mTOR signalling and mediates cancer cell death. Br J Cancer. 2014;110(4):899-907

88. Xiong XX, Liu JM, Qiu XY, Pan F, Yu SB, Chen XQ. Piperlongumine induces apoptotic and autophagic death of the primary myeloid leukemia cells from patients via activation of ROS-p38/JNK pathways. Acta Pharmacol Sin. 2015;36(3):362-74.

89. Wang Y, Wang JW, Xiao X, Shan Y, Xue B, Jiang G, He Q, Chen J, Xu HG, Zhao RX, et al. Piperlongumine induces autophagy by targeting p38 signaling. Cell Death Dis. 2013;4:e824.

90. Lu CH, Chen SH, Chang YS, Liu YW, Wu JY, Lim YP, Yu HI, Lee YR. Honokiol, a potential therapeutic agent, induces cell cycle arrest and program cell death in vitro and in vivo in human thyroid cancer cells. Pharmacol Res. 2017;115:288-98

91. Nazim UM, Jeong JK, Seol JW, Hur J, Eo SK, Lee JH, Park SY. Inhibition of the autophagy flux by gingerol enhances TRAlL-induced tumor cell death. Oncol Rep. 2015;33(5):2331-6.

92. Hsieh MJ, Chen MK, Chen CJ, Hsieh MC, Lo YS, Chuang YC, Chiou HL, Yang SF. Glabridin induces apoptosis and autophagy through JNK1/2 pathway in human hepatoma cells. Phytomed Int J Phytother Phytopharmacol. 2016;23(4):359-66.

\section{Submit your next manuscript to BioMed Central and we will help you at every step:}

- We accept pre-submission inquiries

- Our selector tool helps you to find the most relevant journal

- We provide round the clock customer support

- Convenient online submission

- Thorough peer review

- Inclusion in PubMed and all major indexing services

- Maximum visibility for your research

Submit your manuscript at www.biomedcentral com/submit 